Article

\title{
Service Customer Loyalty: An Evaluation Based on Loyalty Factors
}

\author{
Neringa Vilkaite-Vaitone *(i) and Ilona Skackauskiene \\ Management Department, Vilnius Gediminas Technical University, Sauletekio av. 11, LT-10223 Vilnius, \\ Lithuania; ilona.skackauskiene@vgtu.lt \\ * Correspondence: neringa.vilkaite-vaitone@vgtu.lt
}

Received: 25 January 2020; Accepted: 12 March 2020; Published: 13 March 2020

\begin{abstract}
This study sheds light on customer loyalty based on three groups of factors (customer, service provider, and environment). Noting the diversity of the effects of customer loyalty factors, this research investigates the impact of every factor upon customer loyalty. This paper provides an innovative insight into how a variety of customer loyalty factors might be combined into a single measure of customer loyalty. Finally, this study examines phases of customer loyalty and identifies the factors that prevent a peak of customer loyalty. The factors determining customer loyalty explain why customers move across different loyalty phases over time. The results of the empirical testing confirmed the practical applicability of the suggested approach for evaluating customer loyalty based on these factors. An innovative approach to the evaluation of customer loyalty is essential for marketers because it will help them to evaluate loyalty in cases where data about customer behavior are not collected. The findings of the research contribute to a better understanding of which factors are a viable basis for increasing customer loyalty, specifically in the catering and beauty markets, and offer guidance to marketing managers on how to shift customers to more desirable loyalty phases.
\end{abstract}

Keywords: loyalty; service; service industries; consumption; customer

\section{Introduction}

Companies are experiencing difficulties in attracting and maintaining customers as a result of service markets becoming increasingly competitive. Therefore, the need to motivate customer loyalty is getting stronger. In this environment, loyalty becomes an important marketing tool that is not only to be aimed at the customer, but is also a significant indicator of the success of a business $[1,2]$. Strengthening the focus on the customer places a spotlight on the service providers' profits and the potential development of the sources of income in the future. Therefore, customer loyalty is prioritized as the main aim of an organization and its marketing. It is the biggest asset of any organization and a requirement for the foundation of any organization. The majority of managers understand the importance of the loyalty of their customers and therefore pay attention to increasing the loyalty of existing customers, attracting new loyal customers, and choosing a strategy of customer loyalty management. This is extremely important in mature markets, where expansion to new loyal customers is not possible.

Customer loyalty evaluation is an important condition for the development of customer loyalty. A range of customer loyalty evaluation instruments has been developed by marketing scholars over the last few decades [3-16]. Instruments for the evaluation of customer loyalty can be classified as behavioral, attitudinal, and multidimensional [4-8]. Previous research in the field of customer loyalty evaluation has shown that behavioral data are the superior choice on which to base the evaluation of customer loyalty $[6,8]$; however, in some cases, the required data (value of purchases, frequency of purchases, etc.) might be unavailable or even not collected by a company. An alternative technique 
in such cases would be questionnaire research, which usually concentrates on the evaluation of factors determining customer loyalty $[4,5]$. Even though there is no doubt that an understanding of customer loyalty factors is essential for businesses to survive in an extremely competitive environment, a comprehensive set of customer loyalty factors and their evaluation and synthesis into one particular numerical value representing the level of customer loyalty has not yet been fully demonstrated. A numerical value of this type would be an innovative and expedient choice for the measurement of customer loyalty when the behavioral data essential for the measurement are not available.

The goal of the present research is to contribute to customer loyalty research in the service industry. We do so by proposing a comprehensive set of customer loyalty factors and empirically testing the applicability of the set in cases where behavioral data that are essential for the evaluation of customer loyalty are unavailable. That is, we develop a set of factors and, in a detailed manner, explain every factor's impact on customer loyalty. We test our alternative for the evaluation of customer loyalty in the context of the service industry using data obtained from a catering company and a beauty studio in Lithuania. To summarize, the study is aimed at answering the following research questions:

1. What factors have the potential to reflect customer loyalty in cases when behavioral data are unavailable?

2. What impact does each factor have on customer loyalty and how might these impacts be merged into one loyalty measure?

3. Does the proposed approach reveal customer loyalty in service companies? If so, what are the implications for managers and scholars interested in building loyalty?

The confirmation of the possibility of evaluating customer loyalty based on factors would confirm the aptitude of the chosen factors for this purpose and provide managers with more specific, expedient, and clear guidance in the options of how to evaluate customer loyalty in cases when behavioral data are unavailable. Even though our findings are based on data from a catering company and a beauty studio, we discuss how our research can benefit all service establishments in developing customer loyalty.

The remainder of the article is structured as follows. The next section presents the theoretical background of factors determining customer loyalty. The Materials and Methods section describes the sequence of the research and the data used. The Results section presents the results of our empirical research on customer loyalty in a catering company and at a beauty studio. The Discussion section reviews the theoretical and practical implications of the results. The last section provides conclusions and suggests directions for future research.

\section{Theoretical Background}

\subsection{Factors Determining Customer Loyalty}

Customer loyalty is not a new concept. It has been explored since the 1930s [9]. Since then, many definitions have been suggested. In reference to previous research in the field of customer loyalty, authors have suggested defining this concept as a customer's positive attitude in regards to the service (and its attributes), i.e., an attitude that enhances customer preference in the form of the purchase of certain types of services from a certain provider [17].

Customer loyalty is determined by many factors. Identifying the determinants of loyalty is an initial step in the evaluation of customer loyalty. Over the last four decades, research on customer loyalty factors has been a prolific field. Marketing scholars [9,11,13-16,18-20] have developed and validated more than one hundred different factors determining customer loyalty. Classifications of factors determining customer loyalty show that researchers' opinions on collections of factors vary. The number of factors that determines customer loyalty also varies a lot-researchers indicate between 3 and 30. Notably, authors who analyzed how only one determining factor had an impact on customer loyalty were deliberately not included in this analysis (as an acknowledgement that there are many factors determining customer loyalty) because in these studies, there was only one factor mentioned 
and the rest remained unknown. The factors determining customer loyalty are very wide-ranging, but they have certain specifications that allow them to be divided into categories. However, in scientific sources, there is no agreement on these categories. In most classifications, factors were not grouped at all; nonetheless, there were attempts to allocate factors to: Customer [16], psychological state [19], emotional state [21], service provider [22,23], communications [24], situation [25], marketing mix [26,27], and environment [18].

There is no doubt that the existence of a service is necessary for the occurrence of customer loyalty. This service is provided by the organization that is forming the loyalty. Due to the inseparability between the service itself and the service provider, a group of factors is integrated into the list of service provider factors. External factors may influence both the participants of the process of loyalty creation, i.e., the customer and the service provider. The marketing mix is the result of the organization's functional marketing; therefore, it is not defined as a factor equal to customer, service, service provider, and communications. Psychological and emotional factors form a part of customer factors, but the situational factors of customer loyalty are not included in the classification because the situational factor category is linked with other group factors. Thus, all of the factors determining customer loyalty are divided into three categories by the authors of this article: The customer, the service provider, and the environment characteristics (Figure 1). To determine customer loyalty, it is appropriate to choose those factors that are not accidentally mentioned in other classifications and those that do not overlap with each other.

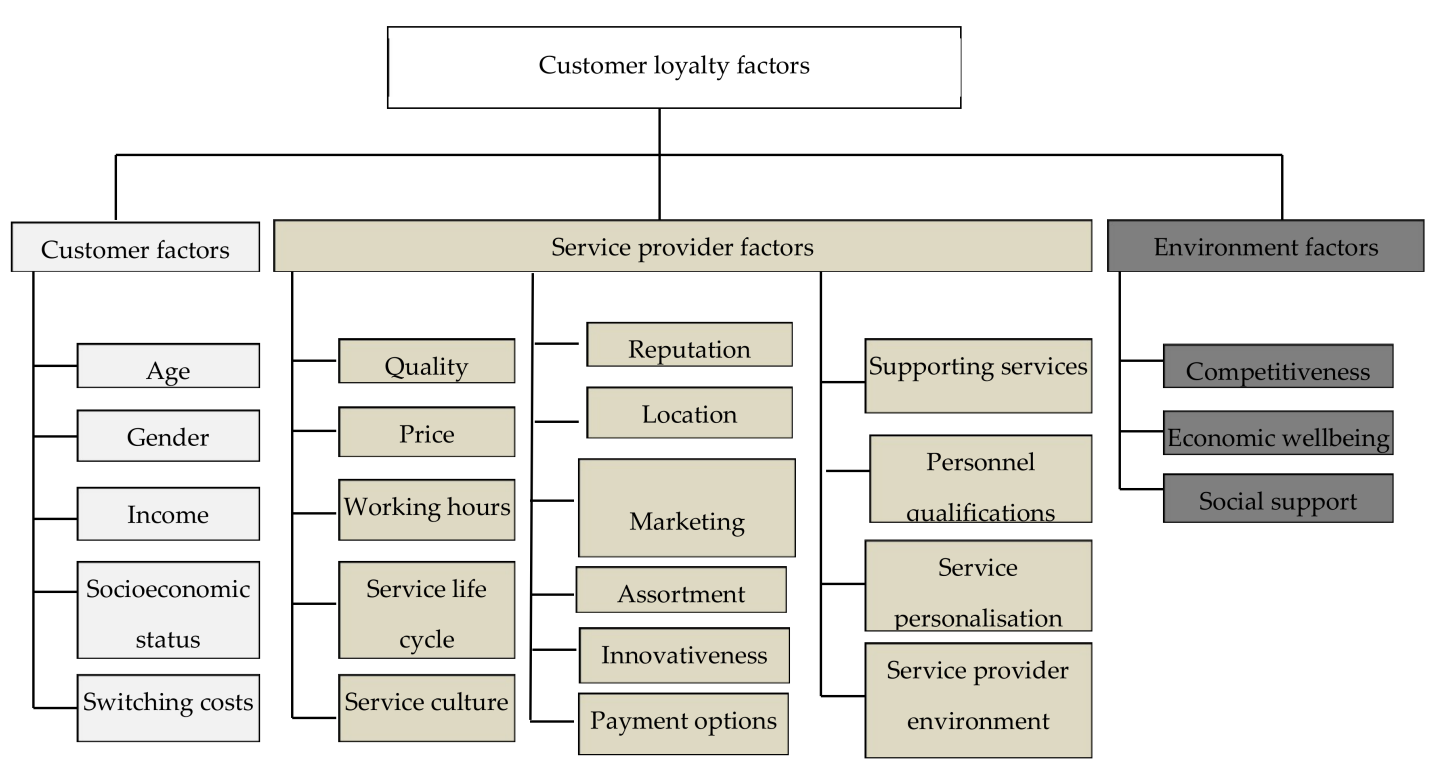

Figure 1. A set of factors determining customer loyalty.

All of the factors that are included in the named categories must be evaluated based on the following principles:

- Scales (names, ranks, and relationship scales) are applied for the evaluation of every factor;

- the effect of each factor on loyalty is evaluated within individual grades; ranks are arranged in ascending order;

- the effect on loyalty is expressed by an index. The meanings of the index may be included in the interval $[-1 ; 1]$; however, characteristics of every factor may adopt different minimum values, depending on their impact on loyalty;

- evaluation of the factors is determined by the standard, average value, maximum value, and the requirements to meet the factor; therefore, some factor evaluations are inseparable from the market. 


\subsection{Customer Factors}

The group of customer factors includes age, gender, income, socioeconomic status, and switching costs. Each of these factors has a certain impact on customer loyalty. As was confirmed by S. Homjitr, Sato [10] and Srivastava [12], loyalty is not the same during different stages of a customer's life. More mature customers show a higher level of loyalty than those who are younger. According to Anderson and Sharp [28], the younger the customer is, the easier it is for a competitor to attract them. More senior customers are less interested in changing service providers, mainly due to the social benefits they may receive, exceptional customer service, and the strong relationship based on trust that has been created. Belas et al. [29] stated that older customers believe that the organization's offer is the best. Older customers are more satisfied with their service; their perceptive value is greater. In particular, loyalty increases when a person's social network narrows down (children leave parental homes, individual retires, etc.). Quite often, it is not a very easy task to fill that social gap. As a result, keeping in touch with service providers becomes an opportunity to fill that social gap. As a customer of the same service provider (e.g., hairdresser, medical center, sports facility, etc.), they are recognizable and, therefore, the customer feels closeness. For senior citizens, such connections are a lot more important than for the younger generation [30]. Older customers tend to be more critical towards change and tend not to have a strong desire to try new things, which leads to a direct and positive correlation between age and loyalty. Taking into consideration all of the factors mentioned above, it can be said that loyalty grows stronger as the age of a customer increases. However, this statement cannot be applied to all services, as some services are never or seldom used by a younger age group (e.g., prosthetic dentistry, kinesiatrics, etc.), or vice versa-a large proportion of the customers of a service is made up of younger people (e.g., night clubs, the education sector, etc.). It is therefore very likely that exceptions in certain services may exist-customer loyalty may become weaker with age, or it may not have such tendencies and is simply different in individual age groups (Table 1). Therefore, the data presented in Table 1 show that stronger customer loyalty among young customers is evident in the transport and security, professional, scientific, and technical fields, as well as in educational services. Information and communication activities cover both younger and older customers. The impact on loyalty by age group on the remaining service groups is direct-loyalty increases as age increases. Since the effect of customer loyalty based on age group varies depending on the type of activity of the service provider, the impact of loyalty must be based on a scale, where the effect on loyalty increases when the age of the customer goes up, or vice versa. If the aim is to evaluate the loyalty of the customers of a service that are not the youngest among the age groups of customers (or vice versa-not the oldest), then, it is suggested that customers' ages be regrouped.

Table 1. The impact on customer loyalty in different age groups by type of service.

\begin{tabular}{|c|c|c|}
\hline Services & Authors & Impact \\
\hline Passenger transport, car servicing & $\begin{array}{l}\text { Parahoo et al. [31], Jiang, Zhang [32], } \\
\text { Bekk et al. [33] }\end{array}$ & \multirow{4}{*}{ Younger customers are more loyal } \\
\hline Graphic design & Loureiro, Holger [34] & \\
\hline $\begin{array}{l}\text { Computer games, IT solutions, instant } \\
\text { messaging }\end{array}$ & Kim, Kim [35] & \\
\hline Physical education & Dragan [36] & \\
\hline Catering & Anderson, Sharp [28] & \multirow{7}{*}{ Older customers are more loyal } \\
\hline $\begin{array}{l}\text { Supply of internet connection, mobile } \\
\text { phone networks }\end{array}$ & $\begin{array}{l}\text { Anderson, Sharp [28], } \\
\text { Cambra-Fierro et al. [37] }\end{array}$ & \\
\hline Insurance, credit cards, banking & $\begin{array}{l}\text { Anderson, Sharp [28], Belas et al. [29], } \\
\text { Tweneboah-Koduah, Farley [25] }\end{array}$ & \\
\hline Car rental, tourism & Anderson, Sharp [28], Patterson [30] & \\
\hline Health care, dentistry & Anderson, Sharp [28], Patterson [30] & \\
\hline Gambling & Prentice [38] & \\
\hline Hairdresser/barber & Patterson [30] & \\
\hline
\end{tabular}


According to Homjitr, Sato [10], Tweneboah-Koduah, Farley [25], and Belas et al. [29], customer behavior is one of the fields where significant differences appear between men and women. Interpersonal communication between women is much stronger than it is between men. Women's shopping behavior is heavily affected by interpersonal relationships. In comparison to men, women are more involved in shopping. Women also experience higher satisfaction in the shopping process. They trust the information they receive while shopping more than men do. Moreover, women go shopping more often and seek better deals more actively than men. Shopping for women is a part of their social identity; they identify the elements of acquiring a tangible product [39]. Their propensity to recommend the services of the organization to their peers is significantly stronger [29]. Customers can be held as a key concept in communications marketing, the main communications marketing goal, or the result of communications marketing. Therefore, women are valued as being superior in maintaining connections and showing stronger customer loyalty to organizations. The weaker loyalty of men is highlighted by Tweneboah-Koduah, Farley [25], and Kamath et al. [40]. The results of this research allow the quantification of the impact of gender on the formation of customer loyalty.

The income of the customer is claimed to be an important factor in customer behavior, and it is included in the segmentation of market decisions. Customer income analysis shows that individuals with lower incomes tend to have stronger loyalties [41,42]. Customers with lower incomes prefer a certain service provider in the majority of cases, as these customers are limited by service choices that are affordable to them. In contrast, customers on higher incomes have the opportunity to constantly change their preferences within a wide range of services [42]. Customers with higher incomes tend to have received higher levels of education. As a result, the quality of communication and information exchange between service providers and higher-earning customers can be more intense, which results in weaker loyalty. In addition, customers with higher incomes have fewer consumption restrictions. To evaluate customer income, the calculation of relative income as a ratio of a customer's monthly income and the highest income in terms of customers of service organizations is suggested. Due to the lower consumption restrictions and the more intensive changes in service providers, a higher relative customer income has a smaller impact on loyalty compared to lower relative customer income, which is seen to have a stronger impact on customer loyalty.

Two types of socioeconomic status are distinguished in the scientific literature: Material status and educational status [43]. Educational status is more important than material status. In addition to that, to evaluate the material status aspect, the income factor has to be taken into consideration. Therefore, the socioeconomic status of service customers is only based on the education factor. There is no doubt in the scientific literature on the relationship between education and customer loyalty; it is agreed that the education factor is significant: Lower educational achievement leads to customer loyalty [25]. Customers with higher education achievements tend to acquire services from more than one provider. This is the case because customers with higher education levels tend to gain more information, process it better, and base their decisions on that information, whereas lower education has the opposite effect; the need for such a solution does not occur. In addition to that, higher education almost always guarantees higher income; as a result, customers with a higher income seem to switch service providers more frequently.

Switching costs are the actual or perceived costs that are incurred in the process of switching from one service provider to another [44]. These costs include search costs, shut-down and set-up costs, integration costs, accrued benefit loss, risk of non-performance and opportunistic behavior, and relationship building costs [45]. It is relatively easy to calculate the costs of search and accrued benefit loss, but it is very difficult to calculate integration, shut-down, and set-up costs; therefore, calculations may be very inaccurate. It must be noted that actual and relative costs in changing service providers may be very different. Because customers can perceive the same costs very differently, it is preferred to calculate the actual costs of changing service providers. It is suggested that these calculations include the shut-down and set-up costs, integration costs, and costs of accrued benefit loss. For the evaluation of customer loyalty, it is suggested that relative costs are calculated as a ratio 
of the switching costs for a particular customer and maximum switching costs in terms of the same service provider. Service providers' ability to create service provider switching costs undoubtedly builds customer loyalty [46]. When the relative switching costs are high, the customer tends not to change service providers. Therefore, relatively larger switching costs make a greater impact on loyalty, whereas the non-existence of switching costs is associated with negative impacts on customer loyalty.

\subsection{Service Provider Factors}

Service provider factors include factors related to the service (e.g., price, product assortment, innovativeness, quality, supporting services, service personalization, service life cycle) and the convenience of its provision (location, working hours). Some factors reveal attractiveness (reputation, marketing, service provider environment attractiveness), while others define other characteristics of the service provider (personnel qualifications, payment options) (Figure 1).

Price is viewed as an important factor, especially for middle-income earners and/or in commodity-based sectors $[13,47]$. Customers tend to compare the price of the service provider of a particular type of service with prices of other providers offering the same service. If the price offered by a particular provider is less than other service providers' prices, it is more likely that the customer will become loyal to that particular provider. However, if the price for the service is a lot larger, the purchase will likely remain a one-off.

Innovation includes the steps by which one organization is quicker to achieve transformation than other organizations. Consequently, the innovativeness of the service is when an unprecedented service is achieved before other organizations. Services may be classified according to their innovativeness in very different ways. According to one of the earliest classifications, the novelty of the service may be classified as follows: (1) Changes in the techno-economic paradigm (significant changes of technology systems affecting the economy); (2) changes in the technology system (changes that have a large-scale impact on various industries); (3) radical innovations (small and localized changes); (4) incremental innovations (small-scale or continuous improvement of a service) [48]. According to Lemy et al. [49], in pursuit of customer loyalty, the service provider must create innovations. Therefore, innovative services strengthen customer loyalty. Since minor changes to the service are considered necessary for any organization that is providing a service, such changes are seen to have little effect on loyalty.

Assortment is defined as all of the products that the organization sells. With reference to Bhatnagar et al. [9], assortment has a significant influence on the customer when choosing one organization over another; the wider the range of products, the more appealing the organization is to the customer. When choosing larger assortment providers, customers know that the likelihood of getting their required service is a lot higher than choosing a provider with a smaller variety of services. Therefore, variety is claimed to be an essential characteristic of assortment. To evaluate service assortment, it is suggested that the number of all of the available types of different options in the organization is calculated and compared to the maximum assortment in organizations providing that particular type of service. The higher the value of the indicator, the higher the probability that the service offered will match the needs of customers. Therefore, a higher value of the indicator is seen as more acceptable as customers are offered a larger range of services.

Supporting services do not contribute towards the main service, but they create additional value to the customer and highlight what an organization offers compared to its competitors. According to Small et al. [50], supporting services complement the main service. To calculate the value of supporting services, it is suggested that the number of services offered in an organization is calculated and compared to the highest number of supporting services in any of the organizations providing that particular type of service. Supporting services, regardless of whether they are provided directly or online, provide extra benefits for the customer. Therefore, providing these services will encourage the formation of a positive opinion about the organization. Supporting services also guarantee additional sales, which increase the values of purchases. As a result, larger relative values of supporting services 
will have a greater impact on customer loyalty, while a low value is linked to a neutral or a very weak impact on loyalty.

Customers may choose to pick certain providers' services based on their quality $[13,14,20]$. Berezny and Konecny [51] state that customers judge service quality based on the number of complaints received. In an attempt to evaluate the quality of service, it is suggested that the customer complaints about the quality of the service of particular organizations received by national institutions are assessed. Normally, these national institutions provide yearly data reports on customer complaints based on different types of services. Therefore, based on this information, the average number of complaints to providers of particular types of services can be determined. By comparing complaints about the service provider with the market average, the relative quality of the services provided by the organization is determined. The better quality of a particular service provider compared to other providers of the same type of service will have a stronger impact on customer loyalty.

When services are not personalized, all customers are offered the same; when their differences and profitability are not taken into consideration, then the added value is very restricted [52]. Personalized service is when any action is taken to adapt the service for a particular customer. Personalization is not a one-dimensional category, but a combination of the following attributes: Process, communications, assortment, price, and location [53]. As service customization increases customer loyalty [54], a growing level of customization has a bigger impact on customer loyalty. The non-personalization of the service is claimed to have no effect on loyalty. The highest level of service personalization, taking into consideration all five features, has a very large influence on customer loyalty.

A positive reputation of a service provider is an intangible asset that guarantees competitive advantages to the service provider. It is proposed that the evaluation of reputation is based on the number of complaints. The total number of complaints does not reflect the real status of the reputation of the organization; therefore, Morgan and Rego [55] suggest calculating the proportion of the complaining customers against all of the customers of the service provider. Researchers [55] found that the average value of this indicator is $20 \%$. A lower value of this indicator shows a better reputation of the service provider, which leads to a stronger impact on loyalty.

The length of a typical working week is from 35 to 40 hours. Therefore, a working week of 35-40 hours is considered to be normal, and its effect on loyalty is considered to be average. Working hours of less than 35 per week or working hours that are planned and known to the customer are considered to be restricted. Very restricted working hours are when access to the service is very limited for the customer and arranged beforehand (Table 2). On the one hand, it is more difficult to acquire the required service when working hours are very restricted, but, on the other hand, this working time is usual in some activities (insurance, night clubs, etc.), and it is therefore considered to have a neutral effect on loyalty. The length of working hours is one of the most important factors for service customers when choosing a specific service provider [56]. As it is more convenient for the customer to use the service at the time that is more acceptable to them, a service provider with unlimited working hours is valued more. This working time increases the likelihood of multiple purchases, as the customer has an opportunity to receive the service at the time that is most convenient to them.

Table 2. Types of service providers with reference to working hours.

\begin{tabular}{ccc}
\hline Number of Working Hours Per Week & Type & Impact on Loyalty \\
\hline Limited to the customer and arranged beforehand & Very restricted & 0.00 \\
Less than 35 & Restricted & 0.25 \\
$35-40$ & Average & 0.50 \\
$41-104$ & Adapted & 0.75 \\
$105-168$ & Unlimited & 1.00 \\
\hline
\end{tabular}

A convenient location increases demand and service usage opportunities. Tripathi [57] suggests measuring the distance between a customer's home or place of work to evaluate the convenience of 
the location. An acceptable distance from the customer's home or place of work may vary greatly depending on the type of service. For example, the acceptable distance from a customer's home or working place varies from $4.83 \mathrm{~km}$ in the case of spatial service brokerage [58] to $10.78 \mathrm{~km}$ in the case of catering [59]. Knowing the acceptable distance between a service organization and a customer's home or place of work is important, and it is recommended that the proportion of customers that live or work $7.80 \mathrm{~km}$ away from the service organization is calculated. If data are available on both the customer's place of living as well as their place of work, then an average of these two distances is used. The convenience of the location is based not only on the distance, but also on sufficient availability of car parking spaces (a $1000 \mathrm{~m}^{2}$ service area requires at least five car parking spaces), the convenience of the horizontal and vertical arrangement of the building, and the level of crime in the area [60]. The location of the organization that meets all of the criteria named above is considered to be excellent, and the one meeting none of the criteria: Dissatisfactory. The former evaluation of location will have either a neutral or a very insignificant effect on customer loyalty.

Personnel qualification involves the professional experience and education of a service provider's personnel [61]. Without a doubt, both features affect customer loyalty, as through work experience, professional experience, and acquired qualifications, a member of a staff learns about customers, who they are, and why they choose the services of the organization. This knowledge is reflected in actions that develop customer loyalty [62]. It is claimed that longer professional experience has a stronger impact on the loyalty of customers. Higher education is also claimed as a condition for stronger customer loyalty, based on the difficulty of gaining access to higher levels of education [63]. To evaluate general staff qualification levels and their impact on customer loyalty, the average of both professional and educational qualifications needs to be calculated.

Customer loyalty also depends on the marketing budget [64]. It is suggested that, to evaluate the impact of marketing budget, the share of the marketing budget in sales should be calculated first [65] and then compared to the relative budget values of other providers of that particular type of service. Higher marketing budgets strengthen customer loyalty [64]; this type of budget shows that more money is spent on attracting customers, and when more are attracted, the likelihood of loyalty is higher. A separate evaluation of marketing budget does not show whether the assets were used effectively; therefore, it is suggested that the valuation of marketing content is supplemented with further assessment. According to Empen et al. [66], the largest share of marketing budgets goes to sales promotion. Therefore, it is useful to calculate the share of expenses for sales promotions in the total marketing budget. The larger the portion of sales promotion expenses in the marketing budget, the stronger the influence on loyalty. Guided by the values of marketing budget and content, the average impact on loyalty can be calculated.

The product life cycle is a period divided into certain stages: It starts with the introduction of the services into the market and ends with their elimination. The traditional model of a product life cycle consists of four phases: Introduction, growth, maturity, and decline [67]. During the introduction stage, the service is new and known very little by customers; it is often ordered only for trial purposes. At this stage, the service is only used by innovative customers. Following the evaluation of the service, these customers spread information about the service, and, therefore, the customer circle expands. It is only natural that at the stage of introduction, the service cannot make a big impact on customer loyalty; however, its impact is bigger than at the stage of extinction. The growth phase of the service is linked to an exceptionally strong relationship between the customer and service provider and, during this stage, the provider adjusts the offer according to the customers' needs regarding price, distribution, and innovation. Due to the growing recognition of the service, it is believed that loyalty for it grows as well. During the maturity stage, sales scales stabilize. At the beginning of the phase, the number of customers stays the same, but later, the number starts to go down due to the appearance of new service providers that offer the same solution service-as a result, sales decrease, which leads to a decline in the effect on loyalty. During the decline phase, the number of sales constantly decline; the service is at risk of extinction and, therefore, it is believed that the effect on loyalty is neutral. 
According to Padma and Wagenseil [68], customer service culture is a system of shared meanings guiding employees in what they should do. Christopher [69] established the following cultural aspects of customer service: The quality of the order placement, timely delivery, order accuracy, and precise billing and returns. To evaluate the culture of customer service, it is suggested that the secret shopper method be used, although it would only consist of the first element of valuation, due to the other elements requiring a deal. The customer service culture of ordering is characterized by the following qualities: The greeting provided by customer service staff, the use of a uniform by members of customer service staff, the advice provided by customer service staff, the capability of customer service staff to provide information about the service, and the ability of staff to determine waiting times (or specify waiting times). A high-quality customer service culture encourages members of staff to focus on the customer, and this is the first step towards the development of an organization that is focused on customer needs, which undoubtedly leads to customer loyalty. This means that a service organization that fulfils more of the attributes of customer service culture claims higher customer loyalty.

Researchers [70,71] established the following ways of paying for services: Cash, card, bank transaction, payment deferral, cheque. The ways that customers prefer to pay for the service can vary and depend on personal customer traits and features of the forms of payment [70]. This means that a service organization that accepts a variety of payment methods claims higher customer loyalty.

The service delivery environment is associated with physical attributes. An attractive service environment would be new, with wide transitions, a creative layout, bright colors, and new and modern equipment. A less attractive environment would be considered to be one with narrower transitions, a darker interior, and older and poorly maintained equipment (some requiring replacement) [66]. Scientists have identified the following physical elements of the service environment: Cleanliness and tidiness, temperature, interior, and ventilation [72,73]. Significant features of these elements have been evaluated in the service environment (Table 3).

Table 3. Elements and features of the service delivery environment.

\begin{tabular}{ccc}
\hline Elements & Author(s) & \multicolumn{1}{c}{ Features } \\
\hline Cleanliness and tidiness & Bashar et al. [73] & $\begin{array}{c}\text { The organization has a cleaning plan, the cleaning plan is } \\
\text { being actioned, and the overall cleanliness of the premises } \\
\text { is appropriate }\end{array}$ \\
\hline Temperature & Bashar et al. [73] & $\begin{array}{c}\text { During the cold season, the temperature is } 18-22^{\circ} \mathrm{C} ; \\
\text { during the warm season, the temperature is } 18-28^{\circ} \mathrm{C}\end{array}$ \\
\hline Interior & Richardson [72], Bashar et al. [73] & $\begin{array}{c}\text { The plan of the interior is customer-friendly; the interior } \\
\text { design has unconventional features; dominant colors in the } \\
\text { premises are attractive to the customers (warm colors- red, } \\
\text { yellow, orange); lighting is sufficient }\end{array}$ \\
\hline Ventilation & Richardson [72], Bashar et al. [73] & $\begin{array}{c}\text { The facility has a ventilation/recuperation system; premises } \\
\text { have fragrance appliances; artificial scents are used }\end{array}$ \\
\hline
\end{tabular}

If the service delivery environment of the organization fulfils the elements (see Table 3), the element expression will have a strong impact on customer loyalty, as an attractive environment increases the likelihood of a larger purchase value [73]. Customer loyalty based on all of the elements of the service provider environment is determined by the number of satisfactory attributes.

\subsection{Environmental Factors}

The last group of factors is that of environmental factors (Figure 1). This encompasses competitiveness, economic wellbeing, and social support.

It is very common to measure organizational competitiveness by profitability, productivity, market share, and other factors [74,75]. To establish customer loyalty, one of the above indicators is purposed to assess competition: Market share. Market share is calculated as a ratio of sales of a particular type of service from a particular provider and the total sales of that particular type of service. The greater the proportion of the organization's market share, the stronger the loyalty of customers is. 
The economic situation in a country can be evaluated within the scope of gross domestic product (GDP) per capita [76]. It is suggested that a comparison of the value of this indicator within the area to the GDP per capita in the country can show the economic situation of a service provider. Given that the growth of GDP is linked to the weakening of customer loyalty due to fewer restrictions on consumerism, the growth of GDP is linked to weaker effects on loyalty.

Customer loyalty also depends on the level of social security in the country [77]. Social support is evaluated as a ratio between the average social support received by customers of a particular service provider and the average income of customers of a particular service provider. Higher values of social support are associated with a higher tendency towards risk and trying different services [78]. Therefore, it is claimed that higher values of average social support will weaken customer loyalty.

\subsection{Estimation of Customer Loyalty Phase}

Customer factors, service provider factors, and environmental factors compose a set of factors determining customer loyalty (Figure 1). All factors can have minimum values individually selected for each factor, depending on their effect on loyalty. Scales, impact intervals, and the courses of impact on loyalty for the evaluation of these factors are outlined in Table 4.

To evaluate customer loyalty based on the evaluation of loyalty factors, it is important not only to have data on the service provider that is being researched, but also trusted data from other organizations that provide the same services.

Customer loyalty evaluation based on loyalty factors allows the evaluation of customer loyalty using the previously developed evaluation indicator system. This type of customer loyalty evaluation allows customer loyalty to be split into levels (Figure 2).

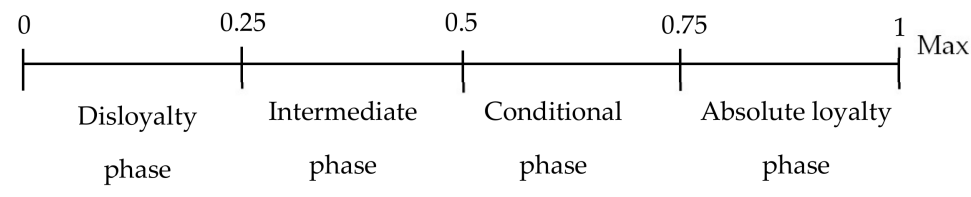

Figure 2. Service customer loyalty evaluation scale and its linguistic interpretation.

Service customer loyalty is divided into four phases: Disloyalty, intermediate loyalty, conditional loyalty, and absolute loyalty. The motivation for the usage of an ordinal scale for the evaluation of customer loyalty is that loyalty is a latent variable that is difficult or even impossible to evaluate directly. The choice of an ordinal scale was also determined by the dominance of the use of these scales in social sciences [79]. The content of disloyal and absolutely loyal customer statuses is clearly described in scientific and professional literature [80,81]. More uncertainty is caused by the intermediate state of loyalty. The customer in an intermediate state is undecided, they are selecting, deliberating, and, at any point, may change their status, but not necessarily toward greater loyalty. The conditional loyalty phase is reached when the loyalty evaluation is above average, but the service customers are not absolutely loyal yet. Absolute loyalty is when a customer does not have any intention of searching for alternative providers of a particular type of service.

Estimations of customer loyalty phases show whether the measures put in place to instigate customer loyalty were selected well and whether their implementation was effective. The value of service customer loyalty farthest from the maximum unit shows that the service provider is not fully utilizing its potential of loyalty. 
Table 4. Scales, impact intervals, and courses of impact on loyalty.

\begin{tabular}{|c|c|c|c|}
\hline Factors & Scales & Impact Interval & Impact on Loyalty \\
\hline Age & Ratio & $0.20-1.00$ & $\begin{array}{l}\text { Every age group has the potential for loyalty. The impact of age on } \\
\text { loyalty depends on the type of service. Younger customers are more } \\
\text { loyal to providers of passenger transport, car servicing, graphic } \\
\text { design, computer games, IT solutions, instant messaging, and } \\
\text { physical education services, while older customers demonstrate } \\
\text { stronger loyalty for providers of catering, internet, mobile phone } \\
\text { networks, insurance, credit cards, banking, car rental, tourism, } \\
\text { health care, dentistry, gambling, and hairdresser/barber services. }\end{array}$ \\
\hline Gender & Nominal & $0.40-0.60$ & $\begin{array}{l}\text { Women, due to their strong aptitude for interpersonal relationships, } \\
\text { have stronger customer loyalty potential than men. }\end{array}$ \\
\hline Income & Ratio & $0.20-1.00$ & $\begin{array}{l}\text { Lower-income customer loyalty is stronger because of the lack of } \\
\text { available choices. }\end{array}$ \\
\hline Socioeconomic status & Ordinal & $0.20-1.00$ & $\begin{array}{l}\text { The loyalty of customers with lower education levels is stronger. } \\
\text { Customers with higher education levels tend to gain more } \\
\text { information, process it better, and base their decisions on that } \\
\text { information. }\end{array}$ \\
\hline Assortment & Ratio & $0.20-1.00$ & $\begin{array}{l}\text { Higher relative assortment (selection) of products makes a stronger } \\
\text { impact on loyalty. }\end{array}$ \\
\hline Innovativeness & Ordinal & $0.00-1.00$ & $\begin{array}{l}\text { Customer loyalty is built on an organization's ability to innovate } \\
\text { services. The more innovative a service is, the higher the impact on } \\
\text { loyalty it has. }\end{array}$ \\
\hline Supporting services & Ratio & $0.00-1.00$ & $\begin{array}{l}\text { The higher the relative value of services, the higher the impact on } \\
\text { loyalty. }\end{array}$ \\
\hline Service personalization & Ordinal & $0.00-1.00$ & $\begin{array}{l}\text { Service personalization has an impact on loyalty. The highest level } \\
\text { of service personalization has the highest impact on loyalty. }\end{array}$ \\
\hline Working hours & Ordinal & $0.00-1.00$ & $\begin{array}{l}\text { An organization that has unlimited working hours is evaluated as } \\
\text { the best in terms of loyalty. }\end{array}$ \\
\hline Location & Ordinal & $0.00-1.00$ & $\begin{array}{l}\text { The location of the organization that is within a reasonable distance } \\
\text { and with an acceptable number of car parking spaces, is on the } \\
\text { ground level, and has a relatively low level of criminal activity } \\
\text { criteria is valued as having the most impact on loyalty. }\end{array}$ \\
\hline Marketing & Ratio & $0.10-1.00$ & $\begin{array}{l}\text { Larger budgets for marketing and a greater sales promotion share in } \\
\text { the marketing budget mean stronger impacts on loyalty. }\end{array}$ \\
\hline $\begin{array}{l}\text { Attractiveness of service } \\
\text { delivery environment }\end{array}$ & Ordinal & $0.00-1.00$ & $\begin{array}{l}\text { A more attractive service delivery environment has a stronger } \\
\text { impact on customer loyalty. }\end{array}$ \\
\hline Reputation & Ratio & $0.00-1.00$ & $\begin{array}{l}\text { A better reputation of the service provider has a stronger impact on } \\
\text { loyalty. }\end{array}$ \\
\hline Service culture & Ordinal & $(-0.25)-1.00$ & $\begin{array}{l}\text { A service organization that fits in with more cultural attributes of } \\
\text { the service customer attracts higher customer loyalty. }\end{array}$ \\
\hline Payment options & Ordinal & $0.00-1.00$ & $\begin{array}{l}\text { A service organization that offers a wider variety of payment } \\
\text { options claims higher customer loyalty. }\end{array}$ \\
\hline Personnel qualifications & Ratio & $(-0.10)-1.00$ & $\begin{array}{l}\text { Higher qualifications of employees are considered to be a stronger } \\
\text { condition of customer loyalty. }\end{array}$ \\
\hline Competitiveness & Ratio & $0.00-1.00$ & $\begin{array}{l}\text { Higher relative market shares of the organization are associated } \\
\text { with a stronger impact on loyalty. }\end{array}$ \\
\hline
\end{tabular}




\section{Materials and Methods}

The application of the suggested set of factors to a catering company and a beauty studio was conducted to evaluate customer loyalty. Both companies are small business units operating in an average-size city in Lithuania (Table 5).

Table 5. Characteristics of the researched companies.

\begin{tabular}{ccc}
\hline Characteristics & Catering Company & Beauty Studio \\
\hline Location & Siauliai, Lithuania & Siauliai, Lithuania \\
Date of establishment & 23 February 2012 & 7 June 2010 \\
Number ef employees (December, 2019) & 9 & 4 \\
Income, EUR (2019) & 25,213 & 40,118 \\
\hline
\end{tabular}

The management of both companies provided specific data from the companies' loyalty program databases and financial reports. The following documents were also requested: Rules for participation in the loyalty program, cleaning plans, temperature logs, room plans, service delivery standards, results from secret shopper researches, CVs of employees, etc. (Table 6). Additional efforts to collect data from customers were not initiated due to the specific approach to the evaluation of customer loyalty: The set of factors used intends to evaluate customer loyalty in cases when behavioral data are unavailable. This approach provides the possibility of evaluating the loyalty of a whole customer base of the company, not of a particular customer.

Table 6. Data sources.

\begin{tabular}{|c|c|c|}
\hline Factors & Data Source & Specification of Data \\
\hline $\begin{array}{l}\text { Age, gender, income, } \\
\text { socioeconomic status, location }\end{array}$ & $\begin{array}{l}\text { Database of the customer loyalty } \\
\text { program }\end{array}$ & $\begin{array}{l}\text { Customers' dates of birth, distribution of customers } \\
\text { according to gender, income, social status, and living place, } \\
\text { number of customers who had complaints during the last } \\
\text { year, number of participants of the customer loyalty } \\
\text { program, number of customers during the last year, the } \\
\text { value of customers' social support }\end{array}$ \\
\hline Switching costs & $\begin{array}{l}\text { Rules of the customer loyalty } \\
\text { program }\end{array}$ & Service provider's switching costs \\
\hline $\begin{array}{l}\text { Assortment, supporting services, } \\
\text { price }\end{array}$ & The price list of services & Number of services provided, prices \\
\hline $\begin{array}{l}\text { Innovativeness, service life cycle, } \\
\text { quality, working hours, } \\
\text { attractiveness of service delivery } \\
\text { environment, reputation, payment } \\
\text { options }\end{array}$ & Interviews with top management & $\begin{array}{l}\text { Innovativeness of services, possibilities to provide services } \\
\text { in electronic environments, possibilities to provide services } \\
\text { in other physical locations, phase of the service life cycle, } \\
\text { number of complaints related to the quality of services, } \\
\text { number of working hours, specification of a ventilation } \\
\text { system, specification of aromatization system, number of } \\
\text { payment options }\end{array}$ \\
\hline $\begin{array}{c}\text { Attractiveness of service delivery } \\
\text { environment }\end{array}$ & Cleaning plan & $\begin{array}{l}\text { (Non-)existence of a cleaning plan, the degree of } \\
\text { compliance with a cleaning plan }\end{array}$ \\
\hline $\begin{array}{l}\text { Attractiveness of service delivery } \\
\text { environment }\end{array}$ & Temperature monitoring system & Temperature monitoring data \\
\hline \multirow[t]{3}{*}{ Marketing } & Financial accounts & Marketing budget, promotion budget, income \\
\hline & Scheme of the building & The layout of the interior \\
\hline & Interviews with personnel & $\begin{array}{l}\text { The number of foreign languages known, possibilities to } \\
\text { adapt services }\end{array}$ \\
\hline $\begin{array}{l}\text { Location, attractiveness of service } \\
\text { delivery environment }\end{array}$ & Photos of interior & Interior design, dominant colors, lighting solutions \\
\hline Service personalization & Service standard & $\begin{array}{l}\text { Possibilities of customer participation in service provision, } \\
\text { possibilities to devote extra time for a customer, } \\
\text { possibilities to advise customers, possibilities for personal } \\
\text { communication with customers, possibilities to } \\
\text { congratulate customers on their birthdays, possibilities to } \\
\text { adapt services, possibilities to adjust the price }\end{array}$ \\
\hline
\end{tabular}


Table 6. Cont.

\begin{tabular}{|c|c|c|}
\hline Factors & Data Source & Specification of Data \\
\hline Location & City scheme & Number of parking spaces \\
\hline Service culture & $\begin{array}{l}\text { Results of a secret shopper } \\
\text { research }\end{array}$ & $\begin{array}{l}\text { The greeting provided by customer service staff, the use of } \\
\text { a uniform by members of customer service staff, the advice } \\
\text { provided by customer service staff, the capability of } \\
\text { customer service staff to provide information about the } \\
\text { service, the ability of staff to determine waiting times (or } \\
\text { specify waiting times) }\end{array}$ \\
\hline Personnel qualifications & CVs of employees & Professional experience, education \\
\hline $\begin{array}{l}\text { Competitiveness, economic } \\
\text { wellbeing, social support }\end{array}$ & Statistics Office & $\begin{array}{l}\text { GDP per capita, the income of organizations providing a } \\
\text { particular service, size of social support }\end{array}$ \\
\hline
\end{tabular}

The collected data let the authors identify the demographic characteristics of the customers of both service providers. The typical customer of the catering company was a female who is $21-40$ years old and has a higher education level. In the case of the beauty studio, the typical customer was female as well; however, the age group of 41-60 years was found to be dominant $(29.19 \%$ of the whole customer base). Customers with a higher education comprised a considerable share of the customer base of the beauty studio.

Methods of content analysis and document analysis were chosen for the analysis of the collected data. Every data source was carefully checked in order to find the required data for the evaluation of every factor. When the analysis of the provided data sources was finished, it was noticed that there were still some informational gaps. To fill them, the management was contacted once again.

Values for factors were determined based on the factor valuation scale, loyalty impact range, and the loyalty effect direction set out in Table 4. Assigning quantifying values to factors makes it possible to calculate the loyalty value, to find out average values of different loyalty groups $[16,18,22,23]$, and to determine the loyalty status: Disloyalty, intermediate, conditional, or absolute loyalty $[80,81]$. We reassured the management of both companies that the results would be used solely for research purposes.

\section{Results}

Customer loyalty to the catering company and the beauty studio services was determined by the evaluation of the impact of customer, service provider, and environmental factors. The results showed that the impacts of factors on loyalty vary widely, from -1 to 1 (Table 7).

Both service providers fell into the category of services where older customers seem to be more loyal (Table 1). Due to the dominance of younger customers in both companies, the impact of age upon customer loyalty was weaker ( 0.48 and 0.47 , respectively). Based on theoretical assumptions and identified scales, impact intervals, and the course of impact on loyalty (Table 4), numeric values of loyalty were attributed to the remaining factors that belong to the customer, service provider, or environmental groups.

Regarding the catering company, among the individual factors, the strongest positive impacts on customer loyalty were quality, reputation, and service culture, whereas the strongest negative effects were made by switching costs (more specifically, the absence of them). The effect of all factors on loyalty was not very strong (0.49). This value of loyalty indicates that the loyalty of customers of the catering company was at the intermediate stage. Factors that belong to the service provider group had the strongest effect on loyalty (0.64) (Figure 3); in terms of these factors, customer loyalty to the catering company is at the conditional stage. The effects of environmental and customer factors on loyalty were significantly weaker ( 0.33 and 0.12 , respectively). Therefore, based on environmental factors, customer loyalty is at the intermediate stage, while the factors of the customer group indicate disloyalty to the catering company. 
Table 7. The impacts of factors on loyalty.

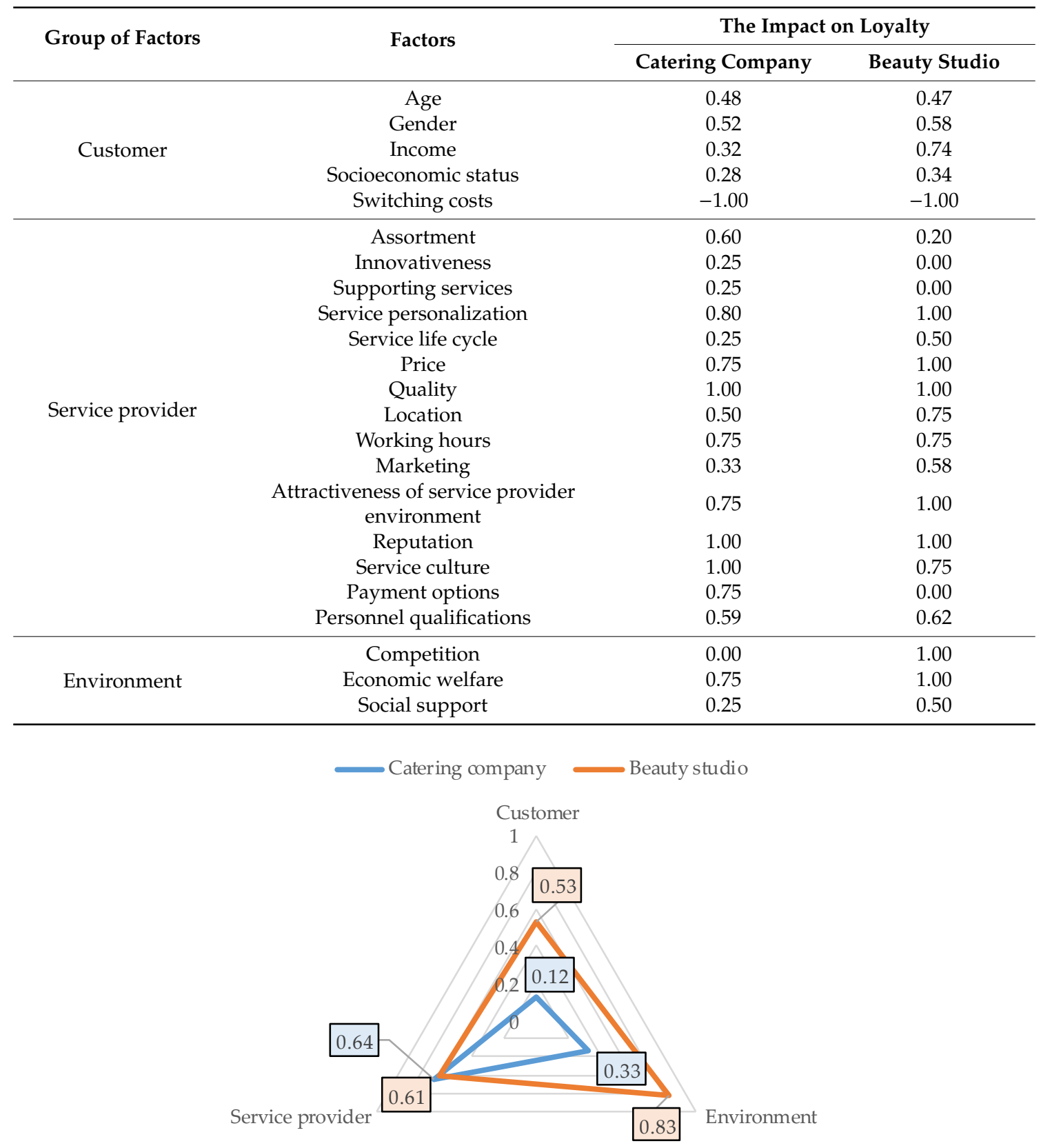

Figure 3. Average values of factors on loyalty by group.

In relation to the beauty studio, service personalization, price, quality, the attractiveness of the environment, reputation, competitiveness, and economic prosperity had the strongest positive effects-all of these factors had a strong impact on loyalty (0.64). When assessing the groups of factors, it can be seen that the environmental factors had the strongest impact on loyalty (0.83). In terms of these factors, the loyalty of the beauty studio customers was at the phase of absolute loyalty. The impacts of the service provider and customer factors on loyalty seemed to be weaker ( 0.61 and 0.53 , respectively). This means that, in terms of the factors mentioned above, service customer loyalty was at the stage of conditional loyalty.

Determining loyalty by measuring the impact of factors is a superior method, as it allows the determination of loyalty-restricting factors and, based on that information, the service provider can choose the most effective tools to promote loyalty. All factors were divided into three groups according to the effect on loyalty (Table 8). 
Table 8. The differentiation of the strengths of factors' impacts on loyalty.

\begin{tabular}{|c|c|c|c|}
\hline \multirow{2}{*}{ Impact on Loyalty } & \multirow{2}{*}{ Strength of Impact } & \multicolumn{2}{|c|}{ Factors } \\
\hline & & Catering Company & Beauty Studio \\
\hline Negative & Very strong & Switching costs & Switching costs \\
\hline Neutral & Neutral & Competitiveness & $\begin{array}{l}\text { Innovativeness, supporting } \\
\text { services, payment options }\end{array}$ \\
\hline \multirow{4}{*}{ Positive } & Very slight & $\begin{array}{c}\text { Innovativeness, supporting } \\
\text { services, service life cycle, social } \\
\text { support }\end{array}$ & Assortment \\
\hline & Slight & $\begin{array}{l}\text { Socioeconomic status, income, } \\
\text { marketing, age, location }\end{array}$ & $\begin{array}{c}\text { Service life cycle, marketing, } \\
\text { personnel qualifications, age, } \\
\text { socioeconomic status, social } \\
\text { support }\end{array}$ \\
\hline & Strong & $\begin{array}{l}\text { Gender, personnel qualifications, } \\
\text { assortment, price, working hours, } \\
\text { attractiveness of service delivery } \\
\text { environment, payment options, } \\
\text { economic wellbeing }\end{array}$ & $\begin{array}{l}\text { Location, working hours, } \\
\text { service culture, gender, income }\end{array}$ \\
\hline & Very strong & $\begin{array}{l}\text { Service personalization, service } \\
\text { quality, reputation, service culture }\end{array}$ & $\begin{array}{c}\text { Service personalization, price, } \\
\text { service quality, attractiveness } \\
\text { of service delivery } \\
\text { environment, reputation, } \\
\text { competitiveness, economic } \\
\text { wellbeing }\end{array}$ \\
\hline
\end{tabular}

The breakdown of customer loyalty factors according to their loyalty trends and strength indicates that the loyalty of the catering service customers was mostly limited by switching costs. Competition was a neutral factor that had neither a positive nor negative effect on customer loyalty. The greatest impacts on customer loyalty were the quality, reputation, and culture of the delivery service. In the beauty studio example, customer loyalty was also mostly limited by switching costs. Innovation, additional services, and payment options were neutral factors that had neither positive nor negative effects on customer loyalty. The greatest impacts on customer loyalty were service personalization, price, quality, the attractiveness of the service delivery environment, reputation, competition, and economic wellbeing. If the beauty studio is aiming for a higher rating of customer loyalty, then all of the other factors should be altered. It should be noted that increasing the value of customer loyalty by $5 \%$ determined an increase in net profit of from $25 \%$ to $85 \%$ [82].

To summarize the evaluation of customer loyalty factors, it can be stated that the service customers of the catering company were at the intermediate loyalty stage, while the beauty studio customers' loyalty was at the conditional stage.

\section{Discussion}

Customer loyalty evaluation has always been of interest to academics and marketers. However, past research into customer loyalty evaluation in cases where behavioral data are unavailable resulted in the choice of questionnaire research. This study sheds light on an alternative by evaluating customer loyalty based on factors.

This research aimed to contribute to customer loyalty research in service industries. To reach this aim, the authors prepared a set of customer loyalty factors for the evaluation of customer loyalty and tested its applicability to service industries. The suggested set of customer loyalty factors supports the findings of other researchers $[16,18,22,23]$ who suggested the classification of factors based on the main participants in loyalty formation, i.e., the customer, the service provider and the environment.

The findings of this theoretical research contribute to marketing literature in several ways. Firstly, we offer a deeper understanding of the typology of factors that determine customer loyalty. Our study reveals that, taking into consideration customer, service provider, and environmental group factors, the impact of every factor can vary from negative to positive. This finding is supported by the 
results of empirical testing on both a catering company and a beauty studio. The study was based on objective data obtained from the service companies. Secondly, this study extends prior research on factors determining customer loyalty by systemically developing a framework for the evaluation of customer loyalty based on the evaluation of every particular factor. We used multiple sources of data to empirically examine how customer, service provider, and environmental characteristics influence the phase of customer loyalty. Our findings, summarized in Figure 2, give a better understanding of which types of factors have a considerable impact on customer loyalty. Our findings suggest important differences in loyalty-building mechanisms between the catering company and the beauty studio. Customer age, service provider assortment, innovativeness, supporting services, service culture, and payment options were found to have considerable impacts on the development of customer loyalty in the catering company. In the case of the beauty studio customers, gender, income, socioeconomic status, switching costs, service personalization, service life cycle, price, quality, location, working hours, marketing, attractiveness of the service provider environment, reputation, personnel qualifications, competition, economic welfare, and social support were all responsible for the increasing customer loyalty to the beauty studio.

We have found that customers may be classified into four phases of loyalty: (1) The disloyalty phase, (2) the intermediate phase, (3) the conditional phase, and (4) the absolute loyalty phase. Customers entering the absolute loyalty phase are the most valuable segment, as they devote a considerable share of their expenditure to that particular service provider. These findings are in line with the results of other research $[80,81]$.

The results of the research provide managers with information about the impacts of customer, service provider and environmental factors on customer loyalty across two different service industries. For a beauty studio seeking absolute customer loyalty, it is important to build in switching costs, increase service innovativeness, expand the range of additional services, and improve payment method options. In the case of the catering company, the following factors should be strengthened: Switching costs, competitiveness, innovativeness, supporting services, service life cycle, and social support. Looking from a managerial perspective, these insights call for changes when designing relationship marketing strategies.

\section{Conclusions}

Customer loyalty factors have been gaining considerable attention in the marketing literature. In this study, we draw on a conceptual set of customer loyalty factors applicable to the evaluation of loyalty in the catering and beauty industries. We have investigated the impact of three particular groups of loyalty factors (i.e., customer, service provider, and environmental) upon the formation of customer loyalty. The results support the applicability of the suggested set of customer loyalty factors. The empirical evidence in this paper reveals failures to establish switching costs in both the catering company and the beauty studio, while the factors that have a strong or very strong positive impact upon customer loyalty in the mentioned industries vary considerably. This research highlights that the service provider factors had the strongest effects on loyalty in the case of the catering company, while the loyalty of the customers of the beauty studio was most intensely impacted by environmental factors. We were able to identify that the loyalty of customers of the catering company was at the intermediate stage, and the loyalty of the customers of the beauty studio indicated conditional loyalty. In order to understand the reasons for these differences, research into other service markets is necessary. In addition, further factors, such as green marketing or greenwashing practices, should be explored.

Our research has some limitations. Even though the objective of the research was to contribute to recent literature examining customer loyalty in the service industry, the aim was reached by testing the applicability of the set of customer loyalty factors for the evaluation of customer loyalty in only two industries. We had to limit the number of researched industries due to data accessibility. The inclusion of additional industries in the research would have substantially confirmed the universality of the suggested set of customer loyalty factors. One more limitation is the failure to test the model in the 
case of e-services. Therefore, it may be interesting to consider customer loyalty and its factors for e-services. Overcoming the mentioned limitations in future studies is expected to be expedient not only to companies providing catering and beauty services, but also to marketers in other areas. We believe that our findings will be interesting for academics and marketers and will provide valuable avenues for future research. For instance, our research on customer loyalty evaluation can be expanded by examining enterprises that represent different channels; for example, online versus offline channels. Furthermore, it would be important to repeat the research in the same catering company and beauty studio after a year or two.

Author Contributions: Conceptualization, I.S. and N.V.-V.; methodology, I.S. and N.V.-V.; formal analysis, I.S. and N.V.-V.; investigation, I.S. and N.V.-V.; resources, I.S. and N.V.-V.; data curation, I.S. and N.V.-V.; writing-original draft preparation, I.S. and N.V.-V.; writing-review and editing, I.S. and N.V.-V.; visualization, N.V.-V.; supervision, I.S. All authors have read and agreed to the published version of the manuscript.

Funding: This research received no external funding.

Conflicts of Interest: The authors declare no conflict of interest.

\section{References}

1. Topcu, B.; Duygun, A. The impacts of customer loyalty on negative word-of-mouth communication and repurchase intention. J. Mark. Manag. 2015, 6, 16-27.

2. Bergel, M.; Frank, P.; Brock, C. The role of customer engagement facets on the formation of attitude, loyalty and price perception. J. Serv. Mark. 2019, 33, 890-903. [CrossRef]

3. Toufaily, E.; Ricard, L.; Perrien, J. Customer loyalty to a commercial website: Descriptive meta-analysis of the empirical literature and proposal of an integrative model. J. Bus. Res. 2013, 66, 1436-1447. [CrossRef]

4. Kamran-Disfani, O.; Mantrala, M.K.; Izquierdo-Yusta, A.; Martinez-Ruiz, M.P. The impact of retail store format on the satisfaction-loyalty link: An empirical investigation. J. Bus. Res. 2017, 77, 14-22. [CrossRef]

5. Srivastava, M.; Kaul, D. Exploring the link between customer experience-loyalty-consumer spend. J. Retail. Consum. Serv. 2016, 31, 277-286. [CrossRef]

6. Bilgihan, A.; Madanoglu, M.; Ricci, P. Service attributes as drivers of behavioral loyalty in casinos: The mediating effect of attitudinal loyalty. J. Retail. Consum. Serv. 2016, 31, 14-21. [CrossRef]

7. Al-hawari, M.A. How the personality of retail bank customers interferes with the relationship between service quality and loyalty. Int. J. Bank Mark. 2015, 33, 41-57. [CrossRef]

8. Bahri-Ammari, N.; Niekerk, M.V.; Khelil, H.B.; Chtioui, J. The effects of brand attachment on behavioral loyalty in the luxury restaurant sector. Int. J. Contemp. Hosp. Manag. 2016, 28, 559-585. [CrossRef]

9. Bhatnagar, S.B.; Syed, A.A.; Mishra, J.K. Identifying customer loyalty supporting factors in the retail banking context: An empirical examination. J. Relatsh. Mark. 2017, 16, 197-225. [CrossRef]

10. Homjitr, S.; Sato, S.C. Factors affecting brand loyalty of essence of chicken brand towards consumers in Bangkok. Utcc Int. J. Bus. Econ. 2017, 9, 33-47.

11. Ou, Y.C.; Verhoef, P.C.; Wiesel, T. The effects of customer equity drivers on loyalty across services industries and firms. J. Acad. Mark. Sci. 2017, 45, 336-356. [CrossRef]

12. Srivastava, R.K. How differing demographic factors impact upon customer loyalty towards national or international fast-food chains: A comparative study in emerging markets. J. Food Prod. Mark. 2017, 23, 901-925. [CrossRef]

13. Gomez, M.; Martin-Consuegra, D.; Diaz, E.; Molina, A. Determinants and outcomes of price premium and loyalty: A food case study. J. Consum. Behav. 2018, 17, 64-74. [CrossRef]

14. Ofori, K.S.; Boakye, K.; Narteh, B. Factors influencing consumer loyalty towards 3G mobile data service providers: Evidence from Ghana. Total Qual. Manag. 2018, 29, 580-598. [CrossRef]

15. Auapinyakul, W.; Deebhijarn, S. A structural equation modelling on factors related to the brand loyalty of diners to certified Thai restaurants in the United States. Asia Pac. Soc. Sci. Rev. 2019, 19, 155-163.

16. Tefera, O.; Migiro, S. The relationship amongst customer satisfaction, loyalty, demographic and tripographic attributes: A case of star rated hotel guests in Ethiopia. J. Econ. Behav. Stud. 2019, 10, 16-29. [CrossRef]

17. Skackauskiene, I.; Vilkaite-Vaitone, N. Paslaugu Vartotojų Lojalumas; Technika: Vilnius, Lithuania, 2017. 
18. Faisal, S.; Hamid, N.A.A.; Abdullah, N.H. Cultural factors affecting persuasive design of smartphone applications to maintain customer loyalty. Adv. Sci. Lett. 2018, 24, 4603-4608. [CrossRef]

19. Jamaludin, M.; Aziz, A.; Mariapan, M. Millennial travellers decision making influenced through user-generated contents and psychological attributes on destination loyalty to a tropical island. J. Tour. Hosp. Environ. Manag. 2018, 3, 44-55.

20. Vazifehdust, H.; Jaberi, M. Factors affecting customer loyalty through satisfaction in traditional retail stores: Structural equation modelling approach. Int. J. Sci. Manag. Dev. 2018, 6, 1-8.

21. Elsäßer, M.; Wirtz, B. Rational and emotional factors of customer satisfaction and brand loyalty in a business-to-business setting. J. Bus. Ind. Mark. 2017, 32, 138-152. [CrossRef]

22. Nyadzayo, M.W.; Khajehzadeh, S. The antecedents of customer loyalty: A moderated mediation model of customer relationship management quality and brand image. J. Retail. Consum. Serv. 2016, 30, 262-270. [CrossRef]

23. Shafei, I.; Tabaa, H. Factors affecting customer loyalty for mobile telecommunication industry. Euromed J. Bus. 2016, 11, 347-361. [CrossRef]

24. Reyes-Menendez, A.; Palos-Sanchez, P.R.; Saura, J.R.; Martin-Velicia, F. Understanding the influence of wireless communications and wi-fi access on customer loyalty: A behavioural model system. Wirel. Commun. Mob. Comput. 2018, 2018,1-16. [CrossRef]

25. Tweneboah-Koduah, E.Y.; Farley, A.Y.D. Relationship between customer satisfaction and customer loyalty in the retail banking sector of Ghana. Int. J. Bus. Manag. 2016, 11, 249-262. [CrossRef]

26. Wu, Y.; Li, E. Marketing mix, customer value, and customer loyalty in social commerce: A stimulus-organism-response perspective. Internet Res. 2018, 28, 74-104. [CrossRef]

27. Othman, B.A.; Harun, A.; Rashid, W.N.; Nazeer, S.; Kassim, A.W.M.; Kadhim, K.G. The influences of service marketing mix on customer loyalty towards Umrah travel agents: Evidence from Malaysia. Manag. Sci. Lett. 2019, 9, 865-876. [CrossRef]

28. Anderson, K.; Sharp, B. Do growing brands win younger consumers? Int. J. Mark. Res. 2010, 52, $433-441$. [CrossRef]

29. Belas, J.; Chocholakova, A.; Gabčova, L. Satisfaction and loyalty of banking customers: A gender approach. Econ. Sociol. 2015, 8, 176-188. [CrossRef]

30. Patterson, P.G. Demographic correlates of loyalty in a service context. J. Serv. Mark. 2007, 21, $112-121$. [CrossRef]

31. Parahoo, S.K.; Harvey, H.L.; Radi, G.Y.A. Satisfaction of tourists with public transport: An empirical investigation in Dubai. J. Travel Tour. Mark. 2014, 31, 1014-1017. [CrossRef]

32. Jiang, H.; Zhang, Y. An investigation of service quality, customer satisfaction and loyalty in China's airline market. J. Air Transp. Manag. 2016, 57, 80-88. [CrossRef]

33. Bekk, M.; Sporrle, M.; Landes, M.; Moser, K. Traits grow important with increasing age: Customer age, brand personality and loyalty. J. Bus. Econ. 2017, 87, 511-531. [CrossRef]

34. Loureiro, S.M.C.; Holger, R. Differential effects of atmospheric cues on emotions and loyalty intention with respect to age under online/offline environment. J. Retail. Consum. Serv. 2014, 21, 211-219. [CrossRef]

35. Kim, S.T.; Kim, J.W. A study of consumer loyalty on instant messaging services. Int. J. Manag. Sci. 2010, 16, $67-80$.

36. Dragan, A.A. Segmenting and profiling fitness club customers: A case study. Rev. Manag. Ing. Econ. 2013, 12, 125-138.

37. Cambra-Fierro, J.; Berbel-Pineda, J.M.; Ruiz-Benitez, R.; Vazquez-Carrasco, R. Managing service recovery processes: The role of customers' age. J. Bus. Econ. Manag. 2011, 12, 503-528. [CrossRef]

38. Prentice, C. Service quality perceptions and customer loyalty in casinos. Int. J. Contemp. Hosp. Manag. 2013, 25, 49-64. [CrossRef]

39. Borges, A.; Babin, B.J.; Spielmann, N. Gender orientation and retail atmosphere: Effects on value perception. Int. J. Retail Distrib. Manag. 2013, 41, 498-511. [CrossRef]

40. Kamath, P.R.; Yogesh, P.P.; Prabhu, K.P. Building customer loyalty in retail banking: A serial-mediation approach. Int. J. Bank Mark. 2019. ahead of print. [CrossRef]

41. Tasci, A.D.A. A quest for destination loyalty by profiling loyal travellers. J. Destin. Mark. Manag. 2017, 6, 207-220. 
42. Orhan, S.; Kaplan, Z. Analysis on brand preference and loyalty of physical education and sports teachers. Univers. J. Educ. Res. 2018, 6, 2471-2477. [CrossRef]

43. Ballew, M.T.; Pearson, A.R.; Goldberg, M.H.; Rosenthal, S.A.; Leiserowitz, A. Does socioeconomic status moderate the political divide on climate change? The roles of education, income, and individualism. Glob. Environ. Chang. 2020, 60, 102024. [CrossRef]

44. Li, Y.; Liu, H.; Lim, E.T.K.; Goh, J.M.; Yang, F.; Lee, M.K.O. Customer's reaction to cross-channel integration in omnichannel retailing: The mediating roles of retailer uncertainty, identity attractiveness, and switching costs. Decis. Support Syst. 2018, 109, 50-60. [CrossRef]

45. Xiao, B.; Feng, Y.; Roche, E. Uncertain switching costs and purchase decisions in electronic markets. Ann. Oper. Res. 2005, 135, 179-196. [CrossRef]

46. Koo, B.; Yu, J.; Han, H. The role of loyalty programs in boosting hotel guest loyalty: Impact of switching barriers. Int. J. Hosp. Manag. 2020, 84, 102328. [CrossRef]

47. Singh, P.K.; Pattanayak, J.K. The impact of brand loyalty on consumers' sportswear brand purchase. IUP J. Brand Manag. 2014, 11, 40-52.

48. Klarin, A. Mapping product and service innovation: A bibliometric analysis and a typology. Technol. Forecast. Soc. Chang. 2019, 149, 119776. [CrossRef]

49. Lemy, D.; Goh, E.; Ferry, J. Moving out of the silo: How service quality innovations can develop customer loyalty in Indonesia's hotels. J. Vacat. Mark. 2019, 25, 462-479. [CrossRef]

50. Small, A.; Russell, S.V.; Paavola, J. Corporate environmental sustainability and ecosystem services: A 21st century solution? In Proceedings of the Academy of Management Annual Meeting, Boston, MA, USA, 9-13 August 2019; Volume 1, pp. 1-5.

51. Berezny, R.; Konecny, V. The impact of the quality of transport services on passenger demand in the suburban bus transport. Procedia Eng. 2017, 192, 40-45. [CrossRef]

52. Torn, I.A.R.; Vaneker, T.H.J. Mass personalization with Industry 4.0 by SMEs: A concept for collaborative networks. Procedia Manuf. 2019, 28, 135-141. [CrossRef]

53. Asif, M.; Krogstie, J. Mobile services personalization evaluation model. Int. J. UE Serv. Sci. Technol. 2013, 6, $1-12$.

54. Wu, C.W. The study of service innovation for digiservice on loyalty. J. Bus. Res. 2014, 67, 819-824. [CrossRef]

55. Morgan, N.A.; Rego, L.L. The value of different customer satisfaction and loyalty metrics in predicting business performance. Mark. Sci. 2006, 25, 426-439. [CrossRef]

56. Flores, M.; Wenzel, T. Shopping hours and price competition with loyal consumers. BE J. Econ. Anal. Policy 2015, 16, 393-407. [CrossRef]

57. Tripathi, S.N. An analysis of customer-pull factors and the process of store loyalty. Paradigm 2009, 9, 91-103. [CrossRef]

58. Ali, R.Y.; Eftelioglu, E.; Shekhar, S.; Athavale, S.; Marsman, E. Supply-demand ratio and on-demand spatial service brokers: A summary of results. In Proceedings of the 9th ACM SIGSPATIAL International Workshop on Computational Transportation Science, San Francisco, CA, USA, 31 October 2016; pp. 7-12.

59. Laska, M.N.; Graham, D.J.; Moe, S.G.; Van Riper, D. Young adult eating and food-purchasing patterns: Food store location and residential proximity. Am. J. Prev. Med. 2010, 39, 464-467. [CrossRef]

60. Waters, S. Choosing a Retail Store Location. 2014. Available online: http://retail.about.com/od/location/a/ selecting_site.htm (accessed on 25 January 2020).

61. Benesova, A.; Tupa, J. Requirements for education and qualification of people in industry 4.0. Procedia Manuf. 2017, 11, 2195-2202. [CrossRef]

62. Wang, C.C.; Wang, Y.M.; Chieh, W.H. The moderating role of customer knowledge on the relationship between satisfaction and loyalty. J. Econ. Bus. Manag. 2016, 4, 292-295. [CrossRef]

63. Ulrich, D.; Brockbank, W. Personalo Vadyba: Vertès Pasiūlymas; Verslo žinios: Vilnius, Lithuania, 2007.

64. Ziliani, C.; Ieva, M. Loyalty in the omnichannel environment. In Loyalty Management. From Loyalty Programs to Omnichannel Customer Experiences; Routledge: New York, NY, USA, 2020.

65. Miller, C.E.; Skudienè, V.; Reardon, J. Managing customer loyalty in the entertainment industry in a transitional economy. Rev. Manag. Innov. Creat. 2013, 6, 114-129.

66. Empen, J.; Loy, J.P.; Weiss, C. Price promotions and brand loyalty. Eur. J. Mark. 2015, 49, 736-759. [CrossRef]

67. Wu, J.; Chang, C.T.; Teng, J.T.; Lai, K.K. Optimal order quantity and selling price over a product life cycle with deterioration rate linked to expiration date. Int. J. Prod. Econ. 2017, 193, 343-351. [CrossRef] 
68. Padma, P.; Wagenseil, U. Retail service excellence: Antecedents and consequences. Int. J. Retail Distrib. Manag. 2018, 46, 422-441. [CrossRef]

69. Christopher, M. Logistika ir Tiekimo Grandinès Valdymas: Pridètinès Vertès Tinklu Kūrimas; Eugrimas: Vilnius, Lithuania, 2007.

70. Shiliashki, M. The untapped potential of digital loyalty programmes. J. Paym. Strategy Syst. 2013, 7, $106-111$.

71. Huynh, K.P.; Nicholls, G.; Shcherbakov, O. Explaining the interplay between merchant acceptance and consumer adoption in two-sided markets for payment methods. Bank Can. Staff Work. Pap. 2019, 32, 1-31.

72. Richardson, P.; Jain, A.K.; Dick, A. The influence of store aesthetics on evaluation of private label brands. J. Prod. Brand Manag. 1996, 5, 19-28. [CrossRef]

73. Bashar, A.; Ahmad, I.; Wasiq, M. A study on influence of demographic factors on consumer impulse buying behaviour. J. Manag. Res. 2013, 13, 145-154.

74. Rodriguez-Pose, A.; Hardy, D. Firm competitiveness and regional disparities in Georgia. Geogr. Rev. 2016, 107, 384-411. [CrossRef]

75. Aguiar, G.P.; Silva, J.C.G.L.; Frega, J.R.; Santana, L.F.; Valerius, J. The use of constant market share (CMS) model to assess Brazil nut market competitiveness. J. Agric. Sci. 2017, 9, 174-180. [CrossRef]

76. Churchill, S.W.; Ivanovski, K. Electricity consumption and economic growth across Australian states and territories. Appl. Econ. 2020, 52, 866-878. [CrossRef]

77. Morgeson, F.; Mithas, S.; Keiningham, T.L.; Aksoy, L. An investigation of the cross-national determinants of customer satisfaction. J. Acad. Mark. Sci. 2011, 39, 198-215. [CrossRef]

78. Pont, M.; McQuilken, L. An empirical investigation of customer satisfaction and loyalty across two divergent bank segments. J. Financ. Serv. Mark. 2005, 9, 344-359. [CrossRef]

79. Arvidsson, R. On the use of ordinal scoring scales in social life cycle assessment. Int. J. Life Cycle Assess. 2019, 24, 604-606. [CrossRef]

80. Ngobo, P.V. The trajectory of customer loyalty: An empirical test of Dick and Basu's loyalty framework. J. Acad. Mark. Sci. 2017, 45, 229-250. [CrossRef]

81. Schneider, P.J.; Zielke, S. Searching offline and buying online-An analysis of showrooming forms and segments. J. Retail. Consum. Serv. 2020, 52, 101919. [CrossRef]

82. Aksoy, L.; Keiningham, T.L.; Oliver, R.L. 3 loyalty: Its many sources and variations. Handb. Serv. Mark. Res. 2014, 37, 37-51.

(C) 2020 by the authors. Licensee MDPI, Basel, Switzerland. This article is an open access article distributed under the terms and conditions of the Creative Commons Attribution (CC BY) license (http://creativecommons.org/licenses/by/4.0/). 